\title{
Accessing HIV awareness and prevention information: South African challenges
}

\author{
Jenni Gobind and Wilfred I. Ukpere* \\ Department of Industrial Psychology and People Management, Faculty of Management, University of Johannesburg, \\ South Africa. \\ Accepted 7 December 2012
}

\begin{abstract}
This paper explores HIV awareness challenges in South Africa (SA) with a particular reference to the South African governments HIV awareness and prevention information dissemination initiatives. It further examines three significant South African legislation, namely the Constitution of the Republic of South Africa 108 of 1996 (Constitution), the Promotion of Access to Information Act 2 of 2000 (PAIA) and the Promotion of Administrative Justice Act 3 of 2000 (PAJA), in order to evaluate the challenges confronting HIV awareness campaign in SA. The paper posits that government's inaction in terms of proper dissemination of information relating to HIV awareness, signalled unconstitutionality based on government's contravention of basic constitutional right. Hence, government's contravention of the constitution need not go unnoticed. If ordinary citizens are held accountable for breaking the law, should government also not be held responsible for the years of torpor with regards to HIV/AIDS information dissemination?
\end{abstract}

Key words: Access, administrative justice, awareness, constitution, dissemination, information, prevention.

\section{INTRODUCTION}

On the $11^{\text {th }}$ of May 2000 the Committee on Economic, Social and Cultural Rights (ESCR) adopted the General Comment No 14 (General Comment) on the right to the Highest Attainable Standard of Health (UN Doc. E/C.12/2004/4). South Africa's adoption of the General Comment No 14 was an important international initiative that clarified the nature and the scope of the right to Health. The state has a legal duty to respect, protect and fulfil the right to health. These duties are resounded in Section 7 (2) of the Constitution of the Republic of South Africa 108 of 1996 (Pillay, 2000:4).

The duty to respect health rights requires the states parties to refrain from interfering directly or indirectly with the enjoyment of the right to health. The duty to protect requires that the state parties take measures that prevent third parties from interfering with the guarantees of the right to health. The duty to fulfil, according to the General Comment requires states parties to adopt appropriate,

\footnotetext{
*Corresponding author. E-mail: wilfredukpere.ajbm@gmail.com.
}

legislative, administrative, budgetary, judicial, promotional and other measures towards the full realisation of the right to health (General Comment No 14).

Obligations of comparable priority according to the General Comment include, taking measures to prevent, treat and control epidemic and endemic diseases, providing education and access to information concerning the main health problem in the community, including methods of preventing and controlling them and various others that are not relevant to the scope of this paper.

The paper explores the lack of continued HIV awareness and prevention information dissemination and government's failure to reduce the continued increase in HIV infection. It further examines section 7 (2) of the Constitution of the Republic of South Africa Act 108 of 1996, extracting relevant rights established in the Constitution and comparing these rights against government's initiatives in the dissemination of HIV awareness and prevention information.

In addition to the Constitution the paper looks at other legislation that may give effect to society's right to HIV awareness and prevention information dissemination. 
Specifically the Promotion of Administrative Justice Act 3 of 2000 (PAJA, 2000) and Promotion of Access to Information Act 2 of 2000 (PAIA, 2000). Such analysis will include the definition of the term information and what constitutes information. The analysis considers government's responsibility in providing such information and the constitutional consequences should government neglect to see the urgency in providing information.

\section{Problem statement}

HIV continues to be a serious concern in SA. The increase in new infections and the spread of infection amongst sexually active individuals begs for an investigation into the effectiveness of the HIV awareness campaign in SA, in order to question parties responsible for the dissemination of HIV awareness and prevention information.

\section{Research question}

The following research question is worth pondering:

(1) Is HIV awareness and prevention information properly disseminated in South Africa?

(2) Is the duty to disseminate HIV awareness information the sole province of the government?

(3) Should government be held responsible for the poor dissemination of HIV information?

\section{The aims and objective of the paper}

The aims and objective of the paper are:

(1) To critically examine the dissemination of HIV awareness and prevention information in South Africa.

(2) To establish the role of the South African government in disseminating HIV awareness information as a means of curtailing and gradually reducing HIV infections in South Africa.

(3) To illustrate why government should be held responsible for the dissemination of HIV awareness and prevention information.

\section{METHODOLOGY}

The paper is a meta-analysis, which relied on secondary sources of information. It is a qualitative study that is based on conceptual analysis (Denscombe, 2007). It considers HIV awareness challenges from an "emic" perspective (author's viewpoint). The analysis has included a comparative review of literature (Kruger \& Wellman, 1999) relating to HIV/AIDS, Human Rights, the Constitution of the Republic of South Africa Act 108 of 1996, Promotion of Administrative Justice Act 3 of 2000, Promotion of Access to Information Act 2 of 2000, and various other pertinent issues.

\section{Comparing South Africa's approach against the general comment}

South Africa falls short in the realisation of health rights as set out in the general comment. The South African Governments inability to deal effectively with the HIV/AIDS crises has been disappointing and is a severe constrain to the realisation of health rights. The ever increasing statistics on HIV/AIDS are indicative of an ineffective prevention strategy (Stats. SA, 2010:3). The estimated overall HIV prevalence rate is approximately $10.5 \%$. The total number of people living with HIV is estimated at approximately 5.25 million in South Africa (Stats SA, 2010:3).

According to Doctor François Venter, President of the South African Clinicians Association, South Africa is currently facing a crisis of prevention as 1000 people a day are infected with HIV. Rates of infection have been increasing since 1991 with a steady increase in the incidences of HIV infection among individuals over the age of 35 (SABCOHA, 2008:1). 'Prevalence among older men and women is rising, which is evidence that the prevention mechanisms and awareness programmes are not reaching these populations. Prevalence for men and women between 50 and 54 was 10.5 and $10.2 \%$ respectively' (Tomli, 2009:1).

Venter outlines that South Africa has not been sophisticated enough about how to tackle HIV prevention. $\mathrm{He}$ further mentions that prevention messages have not been targeted at specific groups. It is the same for people in rural and urban areas. This one-size fits all approach is ineffective (SABCOHA, 2008:1). The Human Science Research Council (HSRC) made an equally disturbing finding in their survey, in that for all the age groups over 15 for both males and females, there has been a decline in accurate knowledge about HIV awareness and prevention from 2005 to 2008 (HSRC, 2008:1). The concern according to the HSRC is that treatment literacy plays an important role in prevention and inaccurate data about HIV will lead to more infections as well as increased stigma and discrimination (Tomli, 2009:1). The HIV/AIDS and STI Strategic Plan for South Africa, 2007 to 2011 confirms that there are 'still too many people newly infected with HIV' (SANAC, 2007).

Government's National Strategic Plan (NSP) target on prevention to reduce transmission by $50 \%$ by 2011 , but according to Tomli $(2009: 1)$ is a distant ideal. Venter (cited in South African Business Coalition (SABCOHA), 2008:2) posited: 'we cannot congratulate ourselves on the NSP if it is not making a difference in the lives of people on the ground. We need to really start evaluating why we aren't reaching the NSP targets'.

\section{CONSTITUTIONALITY: THE RIGHT TO INFORMATION}

'With infection rates as high as $18.8 \%$ in the adult population, and still increasing (SANAC, 2007), 
prevention of further HIV infection is a major priority. Despite this seemingly unquestioned stance, questions remain about whether or not the information is indeed accessible and if so, who is assessing the information (Harvey, 2007:3).

South African society according to Burns (2003) has a constitutional right to protection. Constitutionalism is the doctrine which governs the legitimacy of government action (Burns, 2003:34). The power of the state is therefore defined and limited by law to protect the interest of society. The doctrine of Constitutionalism is prescriptive rather than descriptive: it dictates how state power should be exercised in practice. Boulle et al. (1989) add that Constitutionalism is normative in that it identifies a set of values which should be upheld in the governing process.

\section{THE CONSTITUTION OF THE REPUBLIC OF SOUTH AFRICA}

The Constitution of the Republic of South Africa 108 of 1996 enshrines the rights of individuals in the country and affirms the democratic values of human dignity, equality and freedom (Hassim et al., 2007:9). In addition to 'protecting people's rights to dignity and privacy, the South African Constitution specifically states that the government has a legal duty to respect, protect, promote and fulfil peoples rights' (Hassim et al., 2007:9). In 2001, South Africa lost between 13000 to 250000 adults and children to HIV/AIDS. Six years later in 2007, the figures have doubled from 27000 to 420000 (UNAIDS Report on Global AIDS epidemic, 2008:217). Governments delay in responding begs the question as to whether government is adhering to the provisions of the Constitution.

\section{Administrative law}

According to Large and Wessels (2004:3), administrative law is known as that branch of public law which deals with the body of legal rules, conferring on administrators clothed with state authority, the competence to exercise public power and perform public actions. Secondly, these legal rules prescribed the procedures to be followed when such power is exercised or such function performed, and ensured that the action is within the boundaries of the law.

Baxter (1984) defines general administrative law as the general principles of law which regulate the organisations of administrative institutions and the fairness and efficacy of the administrative process, govern the validity of the liability for administrative action and intention, and govern the administrative and judicial remedies relating to such action or inaction. Large and Wessels (2004:3) have quoted O' Regan (2000) who has observed that administrative law needed to focus on making correct decision rather than relying on judicial review to remedy decisions. O'Regan (2000) explains that the requirements of fairness, efficiency and accountability 'are the three normative requirements that should guide the development of administrative law' (Du Plessis, 2002:159).

Administrative law and more especially the right to just administration finds its origins entrenched in the Constitution of the Republic of South Africa 108 of 1996. Section 33 of the Constitution is known as the just administration action clause. The 'just administration action' clause according to Burns (2003:9-10) encompasses all rules, principles and regulations that govern administrative action, which administration must conform.

'The implications of this clause are the following; the right to just administration action is guaranteed to each and every person as a fundamental right. Administrative justice is ensured by the promotion of administrative openness and accountability via the provision's requirement that reasons for their actions be given by administrative decision making' (Burns, 2003:10). The Promotion of Administrative Justice Act 3 of 2000 (PAJA) was thus promulgated in accordance with Section 33(3) of the Constitution (Republic of South Africa, 1996). It is this section of the Act that is of relevance to the argument presented in the paper. It is understood that parliamentarians may be in charge of formulating legislation, however, it is the administrator appointed under parliamentary authority that are elected to carry out their respective duties as administrators within their separate government departments (Currie and De Waal, 2005:651-652). According to Burns (2003) organs of the state includes all government departments, officials, administrators, public enterprises and tribunals. These public organs and functionaries are subject to the principles laid down in Section 33. Once it has been ascertained whether particular conduct is administrative action, one can turn to the content of the administrative justice rights to establish the duties that the rights place on administrators (Currie and De Waal, 2005:650).

On determining that a decision is an administrative action for the purposes of the PAJA one must then determine whether it is administrative action that requires adherence to fair procedures (Currie and De Waal, 2005:666) or more importantly administrative action which materially affects the rights of a single individual (Section 3 (1) PAJA) or general public (Section 4 PAJA). For the purposes of disseminating HIV awareness and prevention information, the rights of the greater public are important as the objective is to disseminate information to the larger unreachable public. Therefore, Section 4 of the Promotion of Administrative Justice Act 3 of 2000 applies where the rights of members of the public are in issue.

The legal test according to Currie and De Waal (2005:671) is that intention to identify, is applied by investigating 'administrative action that is materially and 
adversely affecting the rights of the public' and is set out as follows that administrative action must:

a) have a great impact,

b) the general impact must have a significant public effect, and

c) rights of members of the public must be in issue.

It is clear from the test set out by Currie and De Waal (2005) that the right to HIV awareness and prevention information satisfies all three conditions. HIV does have a great impact on society, the impact has had considerable effect on society through the loss of lives and thousands of destitute children orphaned and abandoned due to the impact of the virus. The rights of the public are always in issue as they seek employment, health care and deal with stigma each day as victims of the virus. Failure to provide the 'right' to HIV awareness and prevention information will inadvertently result in a contravention of the Constitution and a failure by government to give effect to administrative justice and more importantly failure in disseminating HIV awareness and prevention information.

The need to attain information is crucial in the prevention of HIV infection. It can certainly be said that the old adage 'knowledge is power' is indeed befitting. Information is that resource that can equip an individual to make a life changing decision without hesitation.

Therefore with the new democratic dispensation, information ought to have become more accessible to all. South Africa has to abandon the culture of opaqueness and secrecy to one of openness and transparency. Section 32 of the Constitution realises this transition and has entrenched the broad framework of access to information legislation.

\section{PROMOTION OF ACCESS TO INFORMATION}

In 2000, the Promotion of Access to Information Act 2 of 2000 (PAIA) was enacted (Rajcoomar, 2007:1). The Act places positive obligations on the public sector and on private entities to provide access to information to requestors and to report on their compliance with PAIA (SAHRC, 2008:71). Underpinning the motivation for PAIA it is necessary in the amalgam of elements desirable for a progressive democracy. The key elements therefore encompass both principles of good governance and informed public scrutiny (SAHRC, 2008:71).

It has been extensively argued that the core human rights relevant to HIV/AIDS are those of equality (Section 9, Constitution), dignity (Section 10 of SA Constitution) and freedom of choice especially choice around sexual and health related behaviour (Section 12 of SA Constitution). It could further be argued that the key access to sustaining the ability to uphold and enact these rights is the right to access to information. In other words, every citizen has the right of access to any information that is held by the state, and any information that is held by another person, that is required for the exercise or protection of any rights (Section 329 (1) of SA Constitution) (Harvey, 2007:1).

'The PAIA has laid the ground rules for a human rights culture grounded on knowledge. For the State, the Act provides a tool to fulfil its obligations under the Constitution. It allows the State to gather the necessary information to advance socio-economic rights. The Act provides the courts with an opportunity to widen its inquiry on socio economic rights through additional information that can now be accessed, and to develop innovative remedies in the enforcement of these rights. Most importantly for the public, knowledge is power. This Act can empower civil society to participate meaningfully in the measures adopted by Government towards the realisation of socio-economic rights. This Act can contribute to improving the quality of peoples' (Masuku, 2000:2) lives through being used to access information from Government and private bodies relating to the protection and advancement of socio-economic rights and of course, HIV/AIDS awareness.

In order to choose freely one requires information and in order to acquire information one needs to gain access to information. As aforementioned, Section 32 (1) of the Constitution of the republic of South Africa Act 108 of 1996 stated: "everyone has a right to access to any information that is held by the state and by another that is required for the exercise or protection of any rights". Within the context of HIV and AIDS every citizen has the right of protection to health, dignity and choice (Human Rights Development Report, 2008). 'Living with dignity, with the right to make choices and the ability to control our own bodies, can have a huge effect on our health. Health is also influenced by the choices we make about how we live our lives such as whether to smoke tobacco, drink alcohol' (Hassim et al., 2007:5) or indulge in unprotected sex. These choices are often influenced by an individual's access to information or education on the subject.

Hassim et al. (2007) posited individuals suffer poor health and disease when they live or work in situations where their human rights are not respected. Examples of social and environmental factors, shows that the risk of infection with HIV is much greater among individuals who do not have access to information, who are poor, and who as (married) women do not have full control over their bodies. Access to HIV awareness and prevention information will allow for informed decisions being made when society has to consider their health (Shange, 2007; Swartz \& Roux, 2004). For example, when and how to use a condom or how HIV is transmitted, upholding their dignity for example if they are unfairly dismissed because of their HIV status and making choices that could derail their continued existence. For instance, when an individual is unaware as to the serious threat HIV poses, should he or she refrain from having multiple partners? 
Governments should be obliged to publish annual reports (Calland and Tilley, 2002: XII) on access to information 'so as to make accountability a real and effective source' (Calland and Tilley, 2002:XII). Section 7 of the Constitution imposes on the state an obligation to 'respect, promote and fulfil the rights in the Bills of Rights. This section provides clear obligations on government to provide information which must be given upon request and information which should be made publicly available without the need for requests including information on HIV awareness and prevention that will enable the protection and exercise of rights' (Calland and Tilley, 2002:7). Access to information is indeed crucial as it is through information that the public can hold government to account. Holding governments to account is a crucial part of creating public trust in government.

\section{ANALYSES AND CONCLUSION}

In order to make a good decision, there is a need for reliable information. Currently, there are large amounts of funding being poured into mass media communications as a form of information dissemination, yet there is little examination being done around who the information is aimed at, what kind of information is being disseminated, whether or not the information aligns with the constitutional guarantees, and whether or not the information has any input at all on people's choices regarding health and sexual behaviours.

Non-governmental organisations (NGO), love Life and Soul City have been able improved communication within the discussed domain, yet government continues to lag behind (Tomli, 2009). A major survey undertaken by HSRC in 2008 assessed how these campaigns are being received by the population. Over four-fifths of South Africans had seen or heard at least one aspect of the four campaigns, from less than three-quarters in 2005. Understandably, awareness messages were best received by 15 to 24 year olds, the target audience of many of these campaigns, with $90 \%$ coverage. This declined with age so that just over $60 \%$ of those aged 50 and above had seen or heard at least one of the four campaigns' messages' (HSRC, 2009:76-79).

Although reach of the main national HIV/AIDS communication programmes increased over time (Department of Health Republic of South Africa, 2006), the government's Khomanani Programme had the lowest reach in comparison to other programmes. Reach of all programmes was low for people aged 50 years and older, with $37.8 \%$ of people in this age group not being reached by any programme (HSRC, 2009:78).

"Communication programmes are not reaching all sectors of the population", said Dr Warren Parker, a coinvestigator on the study. "The lack of reach into older age groups has been raised repeatedly in previous studies, yet nearly four out of ten people aged 50 years and older are not reached by any programme" (HSRC, 2009:1).

Despite the improved reach of these awareness campaigns, accurate knowledge about HIV/AIDS seems poor. Of particular worry is the lack of knowledge regarding how to prevent sexual transmission of HIV/AIDS across all age groups and sexes? Less than half of all people surveyed knew of both the preventive effect of condoms and that having fewer sexual partners could reduce the risk of becoming infected. More troubling still, is the fact that accurate knowledge has significantly decreased in recent years (HSRC, 2009:7679).

Lane et al. (2011:634) support the HSRC in their finding and have concluded that there is a need for proper prevention awareness in Soweto. Lane et al. (2011) have inadvertently uncovered a crucial point that the dissemination of HIV awareness and prevention information should be an on-going task. Government should be held responsible for the dissemination of HIV awareness and prevention information by virtue of their obligation to serve and protect (Constitution, Chapter 2, Bill of Rights).

According to Ntlama (2003:273) the rights of access to information as contained in the Constitution was framed with the intention of acting as a tool with which to monitor and claim more effective delivery of basic services as well as accountability to communities from government.

In order for society to gain access to information, government has to make available relevant information that will allow for the making of an informed choice. Government to certain extent, according to Harvey (2007), Venter (2008), Tomli (2009), HSRC (2009), Stats SA (2010), Lane et al. (2011) has failed in their duty to continuously inform the South African society of the nittygritty of HIV/AIDS. Therefore, government has failed to protect its constituents by not adhering to Chapter 2 of the Constitution where the obligation to protect is a Constitutional right; Government has neglected to comply with the provisions set out in the PAIA where information relevant to the wellbeing of society should be made fully known (Society has a right to be informed by virtue of the Constitution and PAIA); Government has ignored to advice administrators as to their role in terms of HIV/AIDS information dissemination (Section 4 of the PAJA).

In conclusion, the above analysis has shown that the government (to an extent) has contravened the constitution of the Republic, in terms of the dissemination of HIV/AIDS awareness information and, as such, allowed the pandemic to escalate. Government's inaction in that specific domain signalled unconstitutionality based on government's contravention of basic constitutional right. Government's contravention of the constitution need not go unnoticed. If ordinary citizens are held accountable for breaking the law, should government also not be held responsible for the years of torpor with 


\section{regards to HIV/AIDS information dissemination?}

\section{REFERENCES}

2007-2011HIV and AIDS and STI Strategic Plan for South Africa (2007). South African National AIDS Council (SANAC). www.doh.gov.za/docs/misc/stratplan-f.html

Baxter, L (1984). Administrative Law. Juta, Wetton

Boulle L, Harris B, Hoexter C (1989). Constitutional and Administrative Law. Capetown: Juta.

Burns Y (2003) Administrative Law under the 1996 Constitution $\left(2^{\text {nd }} E d\right)$. Lexis Nexis, Butterworths, Durban, South Africa.

Calland R, Tilley A (2002). The Right to Know, The Right to live Access to Information and Socio-economic Justice. ODAC Open democracy Advice Centre, Cape Town

Currie I, De Waal J (2005). The Bill of Rights Hand Book. Juta and Co, Ltd Cape Town.

Denscombe M (2007). The Good research guide for small-scale social research projects. $3^{\text {rd }}$ Edition, Open University Press Mc Graw Hill House, England

Department of Health Republic of South Africa: Progress report on Declaration of Commitment on HIV and AIDS (2006). United Nations General Assembly Special Session on HIV and AIDS.

Du Plessie LM (2002) Interpretation of Statues and the Constitution In: Bill Rights Compendium issue 11. Butterworths, Durban.

General Comment No 14 (UN Doc. E/C.12/2004/4).

Harvey E (2007). To choose freely, we need information...The impact of HIV mass media campaigns. ALO AIDS Legal Network, Cape Town

Hassim A, Heywood M, Berger J (Eds), (2007). Health \& Democracy A guide to Human rights, health law and policy in post-apartheid South Africa. Siberlink CC Cape town.

Human Rights Development Report (2008). South African Human Rights Commission. Johannesburg South Africa www.sahrc.org/sahrc_cms/downloadsHRDR_summons.DOC

Human Sciences Research Council (HSRC) (2009). 'South African National HIV Prevalence, Incidence, Behaviour and Communication Survey, 2008: A Turning Tide Among Teenagers?'

Kruger SJ, Wellman JC (1999). Research Methodology for the Business and Administrative Sciences. Oxford University Press, South Africa.
Lane T, Raymond HF, Dladla S, Rasethe J, Struthers H, McFarland W, McIntyre J (2011). High HIV Prevalence Among Men Who Have Sex With Men In Soweto, South Africa: Results From The Soweto Men's $\begin{array}{lll}\text { Study Aids } & \text { Behaviour. }\end{array}$ http://www.ncbi.nlm.nih.gov/pmc/articles/PMC2888758/?tool=pubmed

Large C, Wessels J (Eds) (2004). The Right to Know: South African Promotion of Administrative Justice and Access to Information. Siberlink, Cape Town

Masuku T (2000). Promotion of Access to information Act: Prospects for the protection of socio-economic rights ESR Review Vol 2. No 3 September 2000.

Ntlama N (2003). The Effectiveness of the Promotion of Access to Information Act 2 of 2000 for the protection of socio-economic rights. Stellenbosch Law Review 2003 (2)

Pillay K (2000). Health Rights ESR Review Vol 2. No 3 September 2000

Promotion of Access to Information act No 2 of 2000

Promotion of Administrative Justice Act No 3 of 2000

Rajcoomar U (2007). Access to information your right to know. ALO AIDS Legal Network Cape Town

Republic of South Africa (1996). The Constitution of the Republic of South Africa No 108 of 1996. Pretoria: RSA.

SABCOHO. 28 March 2008. François Venter on the AIDS crises.

Shange, Z (2007). It's not easy for girls to implement knowledge. Behaviour change through access to information. AIDS Legal Network

Stats. SA (2010) 'Mid-year population estimates'

Swartz L, Roux N (2004). A study of local government HIV/AIDS projects in South Africa. Journal of Social Aspects of HIV/AIDS Vol.1 No.2

Tomli C (2009). HSRC Report on HIV Prevalence Incandescence, Behaviour and Communication Survey 2008. Treatment Action Campaign. www.tac.org.za/community/node/2060 retrieved $6 / 12 / 2009$.

UNAIDS (2008). Report on the Global AIDS Epidemic HIV and AIDS Estimates and Data, 2007 and 2001 www.dataunaids.org/pub/GlobalReport/2008/jc_2008_global_reportp p211.234_en.pdf. 